\title{
Androgen Action in the Ovary
}

\author{
Stephen Franks * and Kate Hardy \\ Institute of Reproductive and Developmental Biology, Imperial College London, Hammersmith Hospital, London, \\ United Kingdom
}

Androgen production by the ovary is an essential requirement for normal cyclical secretion of estradiol but its physiological role extends to important actions on both preantral and antral follicle development, including promotion of granulosa cell proliferation. It is likely only in mature antral follicles that androgens encourage apoptosis and consequent follicle atresia, and this may be an important mechanism to ensure mono-follicular ovulation in primates, including humans. Recent studies have provided new insight into the mechanism of androgen signaling in the ovary which involves both genomic and non-genomic effects that are complementary in effecting a cellular response. In polycystic ovary syndrome, a condition characterized by intra-ovarian androgen excess, aberrant development of both preantral and antral follicles is a salient feature. We present evidence that local action of androgens plays a part in such abnormalities. Finally, we review the role of androgens in follicle atresia and conclude that the effects are part of the normal physiology of follicle maturation.

OPEN ACCESS

Edited by:

Jeff M. P. Holly,

University of Bristol, United Kingdom

Reviewed by:

Katja Teerds,

Wageningen University \& Research,

Netherlands

Francisco Prat,

Consejo Superior de Investigaciones

Cientificas (CSIC), Spain

*Correspondence:

Stephen Franks

s.franks@imperial.ac.uk

Specialty section:

This article was submitted to Experimental Endocrinology,

a section of the journal

Frontiers in Endocrinology

Received: 01 June 2018

Accepted: 24 July 2018

Published: 10 August 2018

Citation:

Franks S and Hardy K (2018)

Androgen Action in the Ovary.

Front. Endocrinol. 9:452.

doi: 10.3389/fendo.2018.00452
Keywords: androgen receptor, follicle development, apoptosis, polycystic ovary syndrome, genomic and nongenomic actions, follicle atresia

\section{INTRODUCTION}

Whilst it is well recognized that androgens are an essential substrate for estradiol production by the ovary, the perception persists that androgens have an adverse effect on ovarian follicular development, even under physiological conditions but especially in an environment of androgen excess. This review will focus on the variety of androgen action on normal ovarian function and on the role of androgen excess in the etiology and ovarian manifestations of polycystic ovary syndrome (PCOS), the commonest endocrine disorder in women of reproductive age.

\section{PHYSIOLOGY OF ANDROGEN ACTION IN THE OVARY}

\section{Androgens and Antral Follicle Function}

The cyclical production of estradiol depends upon the availability of androgen, as a steroid precursor and, of course, cyclical changes in gonadotrophins. Under the influence of tonic levels of LH, androgens are produced by the theca cells of antral follicles. In the human ovary, LH receptors are present in theca cells but normally only appear in granulosa cells in mature follicles greater than $10 \mathrm{~mm}$ in diameter (i.e., the antral follicle that is most likely to go on to ovulate) (1). FSH receptors are present exclusively in the granulosa cells. Androgens (predominantly androstenedione and testosterone) diffuse across the basal lamina of the follicle to the granulosa layer where, under the control of FSH, they are converted to estrogen by the action of CYP19 (aromatase) (2). This co-ordinated interaction of gonadotrophins within the follicle is often referred to as the 2-cell, 2-gonadotophin process (2). Androgens may also have a role in the demise of antral follicles that form part of the cohort that undergo further growth in response to the early follicular phase rise in FSH 
but regress in the late follicular phase as FSH levels fall $(1,3)$. This is a physiological mechanism that ensures that in humans (and non-human primates), mono-follicular ovulation is the rule. The ability of androgens to induce atresia in antral follicles has often been cast as a deleterious effect, particularly under conditions of androgen excess (notably PCOS) but the role of androgens may be rather more nuanced than has been described, as suggested below (see "Androgens and follicle atresia revisited").

\section{Androgen Receptor Expression and Androgen Action Throughout Follicle Development}

Although androgen receptor (AR) is found in all three components of the ovarian follicle, granulosa, theca and oocyte $(4,5)$, AR RNA and protein are most abundant in granulosa cells. In the primate ovary, there is little expression of $A R$ in oocyte and theca of antral follicles (6) and in the human fetal ovary, AR expression is confined to somatic cells (7). Gene expression in the human ovary is high in granulosa cells of small antral follicles but reduces in pre-ovulatory follicles (8). AR expression is present in preantral follicles in rodent (9), ovine (10) as well as primate ovary, suggesting a physiological role in follicle development and function over and above the provision of substrate for estrogen production. In the human ovary, AR gene expression can be detected in human preantral follicles from the primary stage onwards (11), whilst AR protein can be observed from the primordial stage, gradually increasing during follicle development so that $100 \%$ of multi-layered, preantral follicles express AR protein (12) (Figure 1). AR gene expression is prominent in human antral follicles but it is noteworthy that peak expression is in small antral follicles (of around $6 \mathrm{~mm}$ in diameter) but is much reduced in larger (about $15 \mathrm{~mm}$ ) antral follicles and lower still in the mature, preovulatory follicle (8). These changes in the level of AR expression during the later stages of follicle development may be important in terms of androgen action on survival or loss of follicles during a normal ovulatory cycle (see section on "Androgens and follicle atresia revisited" below).

There is plentiful evidence to show that androgens stimulate the growth of both preantral and antral follicles in various species (13-20). Androgen action appears be important for normal follicle development and function. Mice lacking AR in the ovary have impaired follicle maturation and reduced litter size (21-23). Recently, Walters and colleagues have shown that in a neuronespecific AR knockout mouse, there is significant disruption of the hypothalamic regulation of gonadotrophins, associated with abnormalities of ovarian follicular development (24). The potent androgen, dihydrotestosterone (DHT) stimulates protein expression of Ki67 (a marker of cell proliferation) in granulosa cells of mouse preantral follicles without effect on apoptosis (20). Androgen also increases responsiveness of granulosa cells to FSH in terms of both growth and expression of key genes involved in steroidogenesis $(15,20,25,26)$. These results reflect those of a seminal series of studies in primate ovary in which Bondy and colleagues demonstrated that in vivo exposure to androgen leads to growth of both preantral and antral follicles and was associated with increased expression of FSH receptor (FSHR) in granulosa cells $(18,27,28)$. AR expression was found to be positively correlated with that of Ki67 and inversely related to apoptotic cell count (27).

In isolated, mouse preantral follicles, incubation with DHT greatly enhances expression of the steroid acute regulatory protein (StAR, a key regulator of steroidogenesis) in response to FSH (20). In the same model, both testosterone and DHT interact with members of the TGF $\beta$ superfamily, most noticeably reducing gene expression of anti-Mullerian hormone (AMH)

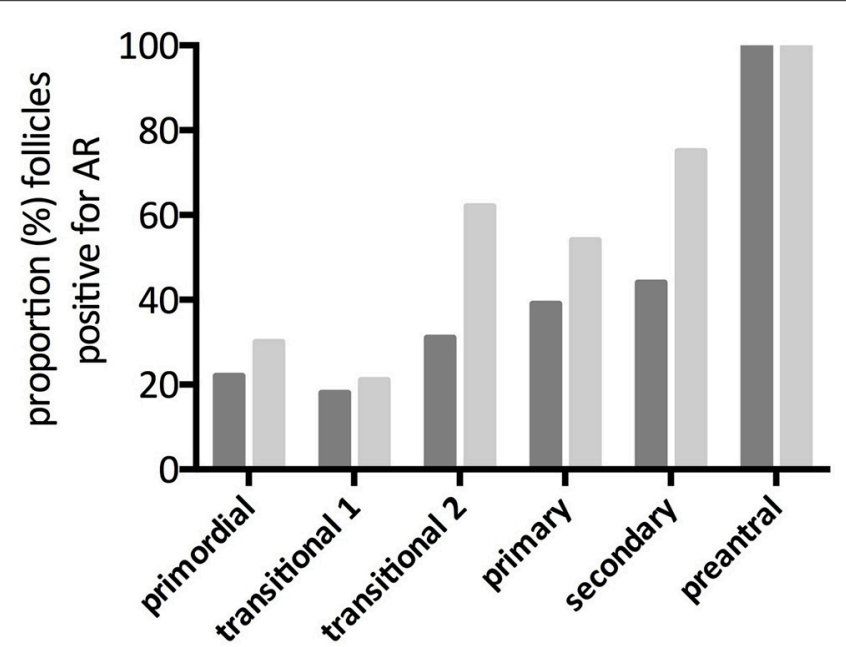

normal ovaries PCOS

stage effect $P=0.0034$

ovary effect $P=0.0462$

(2-way ANOVA) proportion of follicles that stain positive for AR protein. AR expression increased significantly with increasing stage of follicle development in both normal and PCOS (stage effect) but here was a significantly greater abundance of AR in PCO follicles (ovary effect). From Webber (12). 


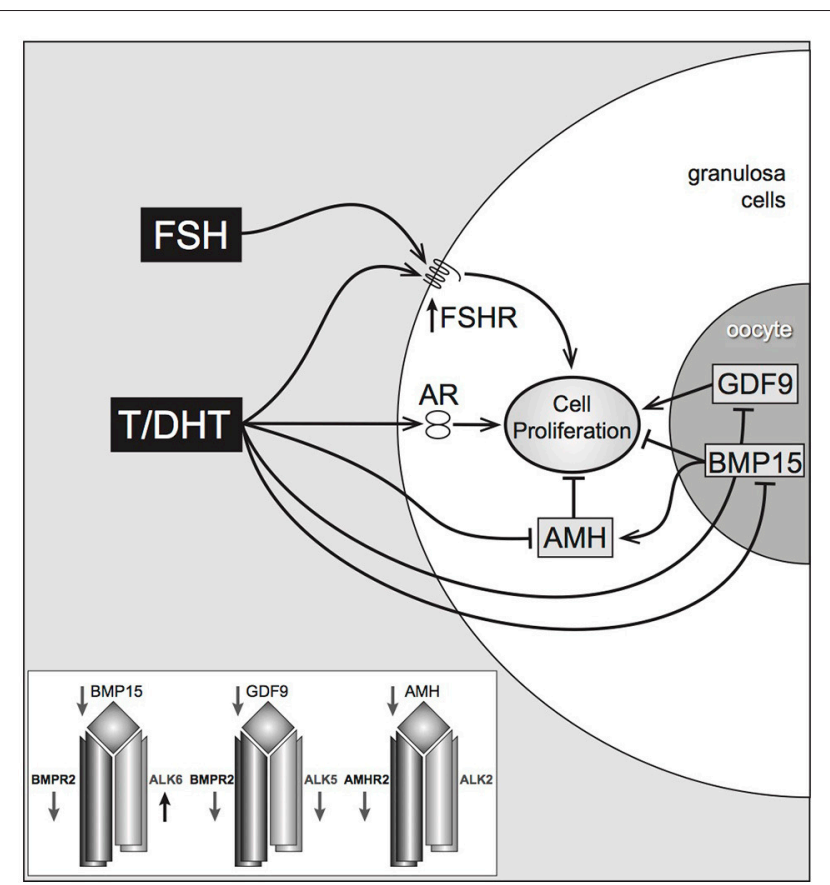

FIGURE 2 | Proposed pathways of androgen action on preantral follicle growth. Testosterone or DHT act via the androgen receptor, increasing granulosa cell proliferation. This may be mediated directly, or indirectly by increased FSHR (stimulating GC proliferation) or decreased $\mathrm{AMH}$ (reducing $\mathrm{AMH}$ inhibition). $\mathrm{AMH}$ can be further reduced by androgen-induced reduction of oocyte-specific BMP, which normally stimulates $\mathrm{AMH}$ levels. Inset box summarizes androgen-induced inhibition of TGF $\beta$ ligands, and type I and II TGF $\beta$ receptors, with the exception of Alk6 Laird et al. (20).

(produced by granulosa cells) and bone morphogenetic protein15 (BMP-15) (produced by the oocyte) both of which may have inhibitory effects on follicle growth (20) (although BMP-15, particularly in the presence of GDF-9 signaling, may also have a stimulatory action on follicle growth) (29). The positive effect of DHT on FSHR expression and the negative effect on the growthinhibitory AMH and BMP-15, suggest that DHT-stimulated growth in preantral follicles is a complex phenomenon that relies upon a balance of endocrine and local growth factor actions (Figure 2). Conversely, there is evidence that BMPs 4, 6, and 7 have inhibitory actions on androgen production by bovine theca (30).

\section{Androgen Signaling in the Ovary}

The classic mode of androgen action, as for most steroids, involves binding of androgen to AR in the cell cytoplasm and translocation of the hormone-receptor complex to the nucleus where it binds to a specific sequence in the promotor of the relevant target gene and promotes gene transcription $(31,32)$. Whilst there is clear evidence that this pathway is operational in both physiological and pathological actions of androgens, recent work suggests that the pathway(s) of androgen signaling are more complex and involve rapid effects that do not involve classic nuclear receptor action on transcription ie non-genomic actions $(22,33,34)$. These non-genomic actions have been highlighted in the work of Sen and colleagues who describe transactivation of the epidermal growth factor receptor (EGFR) by androgen. They show that androgens can activate the MAPK kinase pathway (by phosphorylation of ERK), which, classically, transduces rapid growth factor signaling $(33,35-37)$. In this sense, androgens appear to have growth factor properties. The action of androgens on ERK activation appear to be mediated by matrix metalloproteases (MMPs) and by paxillin (PXN), an adaptor protein which is also implicated in translocation of $\mathrm{AR}$ to the nucleus $(22,36)$. In this way, it is proposed that genomic and non-genomic actions of androgens can be co-ordinated and may work in concert (37). PXN is able to induce expression of the microRNA miR-125b which has an anti-apoptotic effect, hence promoting androgen induced follicle survival (33).

The important finding of an interaction of androgen with the EGFR is supported by data from our own laboratory. Exposure of mouse preantral follicles to a combination of DHT and EGF in culture results in stimulation of growth that is greater than either treatment alone. Furthermore, incubation of follicles with DHT in the presence of an EGF receptor inhibitor results in attenuation of the growth-promoting effect of DHT, strongly suggesting that the effect of androgen on proliferation of granulosa cells is, in part, mediated by activation of EGFR (38).

The EGF signaling pathway is one of several growth factorsignaling pathways with which androgens may interact. As previously mentioned, DHT influences expression of oocyte- and granulosa cell-derived growth factors of the TGF $\beta$ superfamily (20). Androgen can enhance both synthesis and action of insulin-like growth factors (IGFs) $(18,28)$. IGFs signal primarily though the PI3Kinase (PI3K) pathway and recently, Sen and colleagues have provided evidence that androgens also directly activate the PI3K signaling pathway, leading to a complex cascade of events that involve, in an initial and rapid effect, phosphorylation, and thereby inhibition, of the polycomb group protein enhancer of zeste homolog 2 (Ezh2) (34). Ezh2 appears to be a factor in regulation of $\mathrm{LH}$ action in the preovulatory follicle. In the longer term $(24-48 \mathrm{~h})$ the micro RNA miR-101 is induced which, in turn, greatly reduces the expression of Ezh2 protein (34). These findings give further support to their hypothesis that androgen action is likely to involve both genomic and non-genomic events that are closely co-ordinated.

\section{ANDROGENS AND POLYCYSTIC OVARY SYNDROME}

\section{Increased Androgen Production in PCOS}

Polycystic ovary syndrome (PCOS) is the commonest endocrine disorder in women of reproductive age $(39,40)$. Although there is a wide spectrum of clinical presentation, it is typically characterized by infrequent or absent ovulation together with clinical and/or biochemical evidence of androgen excess. The biochemical hall mark of PCOS is excess androgen production, predominantly of ovarian origin $(39,41)$. 


\section{Androgen Action in Polycystic Ovaries}

The systemic effects of androgen excess include cutaneous manifestations (hirsutism, acne, androgenetic alopecia) and predisposition to metabolic derangement (including increased risk of type 2 diabetes mellitus) (42-49). But there are also local actions within the ovary that are characteristic of PCOS. Anovulation in PCOS is distinguished by arrest of growth of antral follicles at $5-8 \mathrm{~mm}$ (50). The mechanism of follicle arrest is complex but is likely to be due to the abnormal endocrine environment that includes excessive secretion of $\mathrm{LH}$, insulin and androgens, all of which may contribute to premature arrest of follicles $(1,50,51)$.

There is, in addition, clear evidence for aberrant development of preantral follicles in the ovaries of women with PCOS. The density of preantral follicles is increased compared with that in normal ovaries and there is a higher proportion of primordial follicles that have been activated and have started to grow (52) with evidence for accumulation ("stockpiling" at the primary stage (53). Small preantral follicles in PCOS show higher expression of the proliferation marker, minichromosome maintenance protein-2 (MCM-2) than that in size matched follicles of normal ovaries (54) and demonstrate prolonged survival in culture (55). These changes in early follicle development can be attributed, at least in part, to the effects of androgen. As described above, androgens stimulate preantral follicle growth in mice, rats, sheep, cows and primates $(16-18,20,56-58)$. In the prenatally androgenised sheep, histological examination of ovarian cortical tissue reveals an increase in the proportion of growing preantral follicles and a reciprocal reduction in the proportion of primordial follicles, a pattern that mimics that seen in human cortical tissue in women with PCOS $(52,58)$.

An interesting question is whether the androgen-growth factor interactions, referred to above, play a part in aberrant early follicle development in PCOS. In that context, it has been shown that both gene and protein expression of the type 1 IGF receptor is increased in preantral follicles of women with PCOS (59). Furthermore, there are differences between normal and polycystic ovaries in growth responsiveness to IGF1 of follicles during culture of cortical tissue which suggest that PCOS follicles have been exposed to enhanced action of IGFs in vivo (59).

It remains unclear whether these aberrations in early follicle development contribute to the characteristic arrest of antral follicles in PCOS but the premature appearance of LH receptors in small antral follicles may provide a clue. Androgens induce FSHR expression and the acquisition of $\mathrm{LH}$ receptors in the dominant follicle that is destined to ovulate is an FSH-dependent event. As yet, we know little about FSHR expression in follicles of women with PCOS but it is noteworthy that cultured granulosa cells from small antral follicles in polycystic ovaries are hyperresponsive to $\mathrm{FSH}$ in terms of estradiol production $(60,61)$.

\section{Androgen and the Developmental Origins of PCOS}

The impact of excess androgen extends beyond the systemic and local effects described above Data from animal models of PCOS suggest that exposure to excess androgen during fetal life may play as significant part in the development of PCOS
(62-67). In rodents, exposure to androgen in postnatal life can also reproduce some of reproductive and metabolic sequelae of PCOS $(56,57)$. Studies using large animal models (sheep, rhesus monkey) provide information that is perhaps more relevant to human PCOS, particularly as ovarian function is similar in terms of follicle development and mono-ovulatory cycles (62, 64, 66, 67). At critical stages during pregnancy, these animals are given very large doses of testosterone which are sufficient to overload the "buffering" of androgen action that occurs during normal pregnancy [elevated maternal plasma levels of sex hormonebinding globulin (SHBG) and activation of placental aromatase] that prevent the fetus being exposed to excess maternal androgen. The fetus is therefore androgenised and, in postnatal life, shows features which replicate many of the characteristics of PCOS including ovarian hyperandrogenism, infrequent or absent ovulation and metabolic dysfunction $(65,66)$. These findings raise the possibility that PCOS is a developmental disorder in which "programming" by excess androgen plays a key role-probably by epigenetic modification $(64,68)$. In human development, the source of excess androgen is unlikely to be maternal androgen (thanks to the protective effect of high, maternal, circulating levels of SHBG and placental aromatase). It is more plausible that, in human PCOS, the source of excess androgen is the ovary itself. We have postulated that the polycystic ovary is genetically predisposed to secrete excess androgen and that androgen excess is manifest, perhaps in the fetal ovary but more likely during the "mini-puberty" of infancy and/or at the onset of puberty itself $(64,68,69)$. Certainly, there is strong evidence for a genetic basis of PCOS. Recent genomewide association studies have indeed identified loci (such as DENND1A) that can be implicated in androgen production by theca cells (70-73).

Further evidence to support the notion that developmental programming by excess androgens plays a part in the origins of PCOS comes from data in women with congenital adrenal hyperplasia $(\mathrm{CAH})$ due to 21-hydroxylase deficiency. Here, of course, the adrenal, rather than ovary is the source of excess androgen in fetal life and beyond. Women with a wellestablished diagnosis of CAH commonly ( $80 \%$ or more) have polycystic ovaries on ultrasound $(74,75)$ and, indeed, may have associated endocrine abnormalities including elevated serum levels of LH (76).

\section{ANDROGENS AND FOLLICLE ATRESIA REVISITED}

There is, as has been illustrated in this review, ample evidence to support the contention that androgens have a positive and, indeed obligatory, role in normal follicle growth and function. These phenomena call into question the widely perceived view that androgens are predominantly detrimental to normal ovarian function. Nevertheless, there is clear evidence that androgens have the ability to inhibit proliferation and promote apoptosis in mature antral follicles as, for example, shown in the rat ovary (77). These apparently paradoxical phenomena can perhaps be best explained by taking into account the stage of follicle 
development. In the menstrual cycle of humans and non-human primates, mono-follicular ovulation is the rule. In such cycles, a single, "dominant" follicle is selected from the cohort of perhaps 5-10 small antral follicles that are recruited by the early follicular phase rise in FSH. Thereafter, it is the follicle that is most responsive to $\mathrm{FSH}$ that continues on the path to ovulation whereas the subsidiary follicles are unable to progress because of the negative feedback on effect on FSH of rising circulating levels of estradiol (and inhibin) (1,50). FSH deficiency clearly plays a role in the atresia of the smaller follicles but, in this context, intra-follicular androgen concentrations appear also to play an important role.

Hillier and colleagues demonstrated a biphasic action of androgens in the ovaries of a non-human primate, the marmoset. In small antral follicles, androgens augmented FSH action on aromatase activity whereas, in larger follicles, androgen had a clear inhibitory effect (26). In a classic study, McNatty and colleagues measured estradiol and androstenedione concentrations in a large number of individual, healthy and atretic human ovarian follicles. Androgen concentrations were similar in healthy and atretic follicles but atretic follicles were characterized by much lower levels of estradiol (3). This has been interpreted as an indication that a high androstenedione to estradiol ratio (i.e., an excess of androgen over estrogen) contributes to (if not causes) follicle atresia. However, it can also be viewed as an effect of FSH deficiency, which itself is

\section{REFERENCES}

1. Hillier SG. Current concepts of the roles of follicle stimulating hormone and luteinizing hormone in folliculogenesis. Hum Reprod. (1994) 9:188-91. doi: 10.1093/oxfordjournals.humrep.a138480

2. Hillier SG, Whitelaw PF, Smyth CD. Follicular oestrogen synthesis: the 'twocell, two-gonadotrophin' model revisited. Mol Cell Endocrinol. (1994) 100:514. doi: 10.1016/0303-7207(94)90278-X

3. Westergaard L, Christensen IJ, McNatty KP. Steroid levels in ovarian follicular fluid related to follicle size and health status during the normal menstrual cycle in women. Hum Reprod. (1986) 1:227-32. doi: 10.1093/oxfordjournals.humrep.a136390

4. Lenie S, Smitz J. Functional AR signaling is evident in an in vitro mouse follicle culture bioassay that encompasses most stages of folliculogenesis. Biol Reprod. (2009) 80:685-95. doi: 10.1095/biolreprod.107.067280

5. Walters KA, Handelsman DJ. Role of androgens in the ovary. Mol Cell Endocrinol. (2018) 465:36-47. doi: 10.1016/j.mce.2017.06.026

6. Hillier SG, Tetsuka M, Fraser HM. Location and developmental regulation of androgen receptor in primate ovary. Hum Reprod. (1997) 12:107-11. doi: 10.1093/humrep/12.1.107

7. Fowler PA, Anderson RA, Saunders PT, Kinnell H, Mason JI, Evans DB, et al. Development of steroid signaling pathways during primordial follicle formati on in the human fetal ovary. J Clin Endocrinol Metab. (2011) 96:1754-62. doi: 10.1210/jc.2010-2618

8. Jeppesen JV, Kristensen SG, Nielsen ME, Humaidan P, Dal Canto M, Fadini $\mathrm{R}$, et al. LH-receptor gene expression in human granulosa and cumulus cells from antral and preovulatory follicles. J Clin Endocrinol Metab. (2012) 97: E1524-31. doi: 10.1210/jc.2012-1427

9. Tetsuka M, Whitelaw PF, Bremner WJ, Millar MR, Smyth CD, Hillier SG. Developmental regulation of androgen receptor in rat ovary. J Endocrinol. (1995) 145:535-43. doi: 10.1677/joe.0.1450535

10. Juengel JL, Heath DA, Quirke LD, McNatty KP. Oestrogen receptor alpha and beta, androgen receptor and progesterone receptor mRNA and protein the major reason for demise of subsidiary follicles. Nevertheless, the striking finding that AR expression, which is high in small antral follicles, is drastically reduced in the healthy, preovulatory follicle (8) points to the removal, or reduction, of a potentially deleterious effect of androgen on granulosa cell survival and function in the mature follicle.

\section{SUMMARY}

In this review, we have provided evidence that androgens have a clear and important physiological role in follicle development, at all stages, and in estrogen production by antral follicles. In PCOS, androgen excess may contribute to aberrant preantral and antral follicle function in PCOS although other endocrine (and paracrine) factors play a part. The role of androgens in causing follicle atresia, in a normal cycle, has probably been exaggerated. FSH deficiency is likely to be the major cause of atresia in subsidiary follicles in mono-ovulatory species but in these estrogen deficient, androgen dominated follicles, androgen action may contribute to follicle loss.

\section{AUTHOR CONTRIBUTIONS}

All authors listed have made a substantial, direct and intellectual contribution to the work, and approved it for publication.

localisation within the developing ovary and in small growing follicles of sheep. Reproduction (2006) 131:81-92. doi: 10.1530/rep.1.00704

11. Rice S, Ojha K, Whitehead S, Mason H. Stage-specific expression of androgen receptor, follicle-stimulating hormone receptor, and anti-Mullerian hormone type II receptor in single, isolated, human preantral follicles: relevance to polycystic ovaries. J Clin Endocrinol Metab. (2007) 92:1034-40. doi: 10.1210/jc.2006-1697

12. Webber LJ. Prentral Follicle Development in Normal and Polycystic Ovaries. PhD Thesis, Imperial College London, Chapter 5 (2005).

13. Nimrod A, Lindner HR. A synergistic effect of androgen on the stimulation of progesterone secretion by FSH in cultured rat granulosa cells. Mol Cell Endocrinol. (1976) 5:315-20.

14. Hillier SG, Knazek RA, Ross GT. Androgenic stimulation of progesterone production by granulosa cells from preantral ovarian follicles: further in vitro studies using replicate cell cultures. Endocrinology (1977) 100:1539-49.

15. Wang XN, Greenwald GS. Synergistic effects of steroids with FSH on folliculogenesis, steroidogenesis and FSH- and hCG-receptors in hypophysectomized mice. J Reprod Fertil. (1993) 99:403-13. doi: 10.1530/jrf.0.0990403

16. Murray AA, Gosden RG, Allison V, Spears N. Effect of androgens on the development of mouse follicles growing in vitro. J Reprod Fertil. (1998) 113:27-33. doi: 10.1530/jrf.0.1130027

17. Yang MY, Fortune JE. Testosterone stimulates the primary to secondary follicle transition in bovine follicles in vitro. Biol Reprod. (2006) 75:924-32. doi: 10.1095/biolreprod.106.051813

18. Vendola KA, Zhou J, Adesanya OO, Weil SJ, Bondy CA. Androgens stimulate early stages of follicular growth in the primate ovary. J Clin Invest. (1998) 101:2622-9. doi: 10.1172/JCI2081

19. Qureshi AI, Nussey SS, Bano G, Musonda P, Whitehead SA, Mason HD. Testosterone selectively increases primary follicles in ovarian cortex grafted onto embryonic chick membranes: relevance to polycystic ovaries. Reproduction (2008) 136:187-94. doi: 10.1530/REP-07-0172 
20. Laird M, Thomson K, Fenwick M, Mora J, Franks S, Hardy K. Androgen stimulates growth of mouse preantral follicles in vitro: interaction with follicle-stimulating hormone and with growth factors of the TGFbeta superfamily. Endocrinology (2017) 158:920-35. doi: 10.1210/en.2016-1538

21. Shiina H, Matsumoto T, Sato T, Igarashi K, Miyamoto J, Takemasa S, et al. Premature ovarian failure in androgen receptor-deficient mice. Proc Natl Acad Sci USA. (2006) 103:224-9. doi: 10.1073/pnas.0506736102

22. Sen A, Hammes SR. Granulosa cell-specific androgen receptors are critical regulators of ovarian development and function. Mol Endocrinol. (2010) 24:1393-403. doi: 10.1210/me.2010-0006

23. Walters KA, Middleton LJ, Joseph SR, Hazra R, Jimenez M, Simanainen U, et al. Targeted loss of androgen receptor signaling in murine granulosa cells of preantral and antral follicles causes female subfertility. Biol Reprod. (2012) 87:151. doi: 10.1095/biolreprod.112.102012

24. Walters KA, Edwards MC, Tesic D, Caldwell ASL, Jimenez M, Smith JT, et al. The Role of Central Androgen Receptor Actions in Regulating the Hypothalamic-Pituitary-Ovarian Axis. Neuroendocrinology (2018) 106:389400. doi: 10.1159/000487762

25. Dorrington JH, McKeracher HL, Chan AK, Gore-Langton RE. Hormonal interactions in the control of granulosa cell differentiation. J Steroid Biochem. (1983) 19:17-32.

26. Harlow CR, Shaw HJ, Hillier SG, Hodges JK. Factors influencing folliclestimulating hormone-responsive steroidogenesis in marmoset granulosa cells: effects of androgens and the stage of follicular maturity. Endocrinology (1988) 122:2780-7.

27. Weil SJ, Vendola K, Zhou J, Adesanya OO, Wang J, Okafor J, et al. Androgen receptor gene expression in the primate ovary: cellular localization, regulation, and functional correlations. J Clin Endocrinol Metab. (1998) 83:2479-85.

28. Vendola K, Zhou J, Wang J, Bondy CA. Androgens promote insulin-like growth factor-I and insulin-like growth factor-I receptor gene expression in the primate ovary. Hum Reprod. (1999) 14:2328-32.

29. Fenwick MA, Mora JM, Mansour YT, Baithun C, Franks S, Hardy K. Investigations of TGF-beta signaling in preantral follicles of female mice reveal differential roles for bone morphogenetic protein 15. Endocrinology (2013) 154:3423-36. doi: 10.1210/en.2012-2251

30. Glister C, Richards SL, Knight PG. Bone morphogenetic proteins (BMP)-4,-6, and-7 potently suppress basal and luteinizing hormoneinduced androgen production by bovine theca interna cells in primary culture: could ovarian hyperandrogenic dysfunction be caused by a defect in thecal BMP signaling? Endocrinology (2005) 146:1883-92. doi: 10.1210/en.2004-1303

31. Simental JA, Sar M, Lane MV, French FS, Wilson EM. Transcriptional activation and nuclear targeting signals of the human androgen receptor. $J$ Biol Chem. (1991) 266:510-8.

32. Askew EB, Minges JT, Hnat AT, Wilson EM. Structural features discriminate androgen receptor N/C terminal and coactivator interactions. Mol Cell Endocrinol. (2012) 348:403-10. doi: 10.1016/j.mce.2011.03.026

33. Sen A, Prizant H, Light A, Biswas A, Hayes E, Lee HJ, et al. Androgens regulate ovarian follicular development by increasing follicle stimulating hormone receptor and microRNA-125b expression. Proc Natl Acad Sci USA. (2014) 111:3008-13. doi: 10.1073/pnas.1318978111

34. Ma X, Hayes E, Biswas A, Seger C, Prizant H, Hammes SR et al. Androgens Regulate Ovarian Gene Expression Through Modulation of Ezh2 Expression and Activity. Endocrinology (2017) 158:2944-54. doi: 10.1210/en.201700145

35. Sen A, O'Malley K, Wang Z, Raj GV, Defranco DB, Hammes SR. Paxillin regulates androgen- and epidermal growth factor-induced MAPK signaling and cell proliferation in prostate cancer cells. J Biol Chem. (2010) 285:2878795. doi: 10.1074/jbc.M110.134064

36. Sen A, De Castro I, Defranco DB, Deng FM, Melamed J, Kapur P, et al. Paxillin mediates extranuclear and intranuclear signaling in prostate cancer proliferation. J Clin Invest. (2012) 122:2469-81. doi: 10.1172/JCI62044

37. Prizant H, Gleicher N, Sen A. Androgen actions in the ovary: balance is key. $J$ Endocrinol. (2014) 222: R141-51. doi: 10.1530/JOE-14-0296

38. Thomson K, Mora, J,M.,Laird, M., Hardy, K. Investigating a role for the epidermal growth factor receptor in androgen signalling within mouse preantral follicle development. Reprod Abstracts. (2015) 2:O016. doi: 10.1530/repabs.2.O016
39. Franks S. Polycystic ovary syndrome. N Engl J Med. (1995) 333:853-61. doi: 10.1056/NEJM199509283331307

40. Ehrmann DA. Polycystic ovary syndrome. N Engl J Med. (2005) 352:1223-36 doi: 10.1056/NEJMra041536

41. Gilling-Smith C, Story H, Rogers V, Franks S. Evidence for a primary abnormality of thecal cell steroidogenesis in the polycystic ovary syndrome. Clin Endocrinol (Oxf) (1997) 47:93-9.

42. Dunaif A, Graf M, Mandeli J, Laumas V, Dobrjansky A. Characterization of groups of hyperandrogenic women with acanthosis nigricans, impaired glucose tolerance, and/or hyperinsulinemia. J Clin Endocrinol Metab. (1987) 65:499-507.

43. Robinson S, Chan SP, Spacey S, Anyaoku V, Johnston DG, Franks S. Postprandial thermogenesis is reduced in polycystic ovary syndrome and is associated with increased insulin resistance. Clin Endocrinol (Oxf) (1992) 36:537-43. doi: 10.1111/j.1365-2265.1992.tb02262.x

44. Robinson S, Henderson AD, Gelding SV, Kiddy D, Niththyananthan R, Bush A, et al. Dyslipidaemia is associated with insulin resistance in women with polycystic ovaries. Clin Endocrinol (Oxf) (1996) 44:277-84.

45. Dunaif A. Insulin resistance and the polycystic ovary syndrome: mechanism and implications for pathogenesis. Endocr Rev. (1997) 18:774-800.

46. Dunaif A. Perspectives in polycystic ovary syndrome: from hair to eternity. $J$ Clin Endocrinol Metab. (2016) 101:759-68. doi: 10.1210/jc.2015-3780

47. Moran LJ, Misso ML, Wild RA, Norman RJ. Impaired glucose tolerance, type 2 diabetes and metabolic syndrome in polycystic ovary syndrome: a systematic review and meta-analysis. Hum Reprod Update. (2010) 16:347-63. doi: 10.1093/humupd/dmq001

48. Joham AE, Ranasinha S, Zoungas S, Moran L, Teede HJ. Gestational diabetes and type 2 diabetes in reproductive-aged women with polycystic ovary syndrome. J Clin Endocrinol Metab. (2014) 99:E447-52. doi: 10.1210/jc.2013-2007

49. Couto Alves A, Valcarcel B, Makinen VP, Morin-Papunen L, Sebert $\mathrm{S}$, Kangas AJ, et al. Metabolic profiling of polycystic ovary syndrome reveals interactions with abdominal obesity. Int J Obes. (2017) 41:1331-40. doi: 10.1038/ijo.2017.126

50. Franks S, Stark J, Hardy K. Follicle dynamics and anovulation in polycystic ovary syndrome. Hum Reprod Update. (2008) 14:367-78. doi: 10.1093/humupd/dmn015

51. Willis DS, Watson H, Mason HD, Galea R, Brincat M, Franks S. Premature response to luteinizing hormone of granulosa cells from anovulatory women with polycystic ovary syndrome: relevance to mechanism of anovulation. $J$ Clin Endocrinol Metab. (1998) 83:3984-91.

52. Webber LJ, Stubbs S, Stark J, Trew GH, Margara R, Hardy K, et al. Formation and early development of follicles in the polycystic ovary. Lancet (2003) 362:1017-21. doi: 10.1016/S0140-6736(03)14410-8

53. Maciel GA, Baracat EC, Benda JA, Markham SM, Hensinger K, Chang RJ, et al. Stockpiling of transitional and classic primary follicles in ovaries of women with polycystic ovary syndrome. J Clin Endocrinol Metab. (2004) 89:5321-7. doi: 10.1210/jc.2004-0643

54. Stubbs SA, Stark J, Dilworth SM, Franks S, Hardy K. Abnormal preantral folliculogenesis in polycystic ovaries is associated with increased granulosa cell division. J Clin Endocrinol Metab. (2007) 92:4418-26. . doi: $10.1210 /$ jc. 2007-0729

55. Webber LJ, Stubbs SA, Stark J, Margara RA, Trew GH, Lavery SA, et al. Prolonged survival in culture of preantral follicles from polycystic ovaries. $J$ Clin Endocrinol Metab. (2007) 92:1975-8. doi: 10.1210/jc.2006-1422

56. Manneras L, Cajander S, Holmang A, Seleskovic Z, Lystig T, Lönn $\mathrm{M}$, et al. A new rat model exhibiting both ovarian and metabolic characteristics of polycystic ovary syndrome. Endocrinology (2007) 148:378191. doi: 10.1210/en.2007-0168

57. van Houten EL, Kramer P, McLuskey A, Karels B, Themmen AP, Visser JA. Reproductive and metabolic phenotype of a mouse model of PCOS. Endocrinology (2012) 153:2861-9. doi: 10.1210/en.20 11-1754

58. Forsdike RA, Hardy K, Bull L, Stark J, Webber LJ, Stubbs S, et al. Disordered follicle development in ovaries of prenatally androgenized ewes. J Endocrinol. (2007) 192:421-8. doi: 10.1677/joe.1.07097

59. Stubbs SA, Webber LJ, Stark J, Rice S, Margara R, Lavery S, et al. Role of Insulin-like growth factors in initiation of follicle growth in normal and 
polycystic human ovaries. J Clin Endocrinol Metab. (2013) 98:3298-305. doi: 10.1210/jc.2013-1378

60. Erickson GF, Garzo VG, Magoffin DA. Insulin-like growth factor-I regulates aromatase activity in human granulosa and granulosa luteal cells. J Clin Endocrinol Metab. (1989) 69:716-24. doi: 10.1210/jcem-69-4-716

61. Mason HD, Willis DS, Beard RW, Winston RM, Margara R, Franks S. Estradiol production by granulosa cells of normal and polycystic ovaries: relationship to menstrual cycle history and concentrations of gonadotropins and sex steroids in follicular fluid. J Clin Endocrinol Metab. (1994) 79:1355-60.

62. Franks S. Animal models and the developmental origins of polycystic ovary syndrome: increasing evidence for the role of androgens in programming reproductive and metabolic dysfunction. Endocrinology (2012) 153:2536-8. doi: 10.1210/en.2012-1366

63. Roland AV, Moenter SM. Reproductive neuroendocrine dysfunction in polycystic ovary syndrome: insight from animal models. Front Neuroendocrinol. (2014) 35:494-511. doi: 10.1016/j.yfrne.2014.04.002

64. Abbott DH, Dumesic DA, Franks S. Developmental origin of polycystic ovary syndrome - a hypothesis. J Endocrinol. (2002) 174:1-5. doi: $10.1677 /$ joe.0.1740001

65. Hogg K, Young JM, Oliver EM, Souza CJ, McNeilly AS, Duncan WC. Enhanced thecal androgen production is prenatally programmed in an ovine model of polycystic ovary syndrome. Endocrinology (2012) 153:450-61. doi: 10.1210/en.2011-1607

66. Abbott DH, Nicol LE, Levine JE, Xu N, Goodarzi MO, Dumesic DA. Nonhuman primate models of polycystic ovary syndrome. Mol Cell Endocrinol. (2013) 373:21-8. doi: 10.1016/j.mce.2013.01.013

67. Padmanabhan V, Veiga-Lopez A. Sheep models of polycystic ovary syndrome phenotype. Mol Cell Endocrinol. (2013) 373:8-20. doi: 10.1016/j.mce.2012.10.005

68. Gorry A, White DM, Franks S. Infertility in polycystic ovary syndrome: focus on low-dose gonadotropin treatment. Endocrine (2006) 30:27-33. doi: 10.1385/ENDO:30:1:27

69. Jayasena CN, Franks S. The management of patients with polycystic ovary syndrome. Nat Rev Endocrinol. (2014) 10:624-36. doi: $10.1038 /$ nrendo.2014.102

70. Chen ZJ, Zhao H, He L, Shi Y, Qin Y, Shi Y, et al. Genome-wide association study identifies susceptibility loci for polycystic ovary syndrome on chromosome 2p16.3, 2p21 and 9q33.3. Nat Genet. (2011) 43:55-9. doi: $10.1038 /$ ng.732
71. McAllister JM, Modi B, Miller BA, Shi Y, Qin Y, Shi Y, et al. Overexpression of a DENND1A isoform produces a polycystic ovary syndrome theca phenotype. Proc Natl Acad Sci USA. (2014) 111: E1519-27. doi: 10.1073/pnas.14005 74111

72. Hayes MG, Urbanek M, Ehrmann DA, Armstrong LL, Lee JY, Sisk R, et al. Genome-wide association of polycystic ovary syndrome implicates alterations in gonadotropin secretion in European ancestry populations. Nat Commun. (2015) 6:7502. doi: 10.1038/ncomms8502

73. Day FR, Hinds DA, Tung JY, Stolk L, Styrkarsdottir U, Saxena R, et al. Causal mechanisms and balancing selection inferred from genetic associations with polycystic ovary syndrome. Nat Commun. (2015) 6:8464. doi: 10.1038 /ncomms 9464

74. Hague WM, Adams J, Rodda C, , Brook CG, de Bruyn R, Grant DB, et al. The prevalence of polycystic ovaries in patients with congenital adrenal hyperplasia and their close relatives. Clin Endocrinol (Oxf) (1990) 33:501-10.

75. Carmina E, Dewailly D, Escobar-Morreale HF, Kelestimur F, Moran C, Oberfield $\mathrm{S}$, et al. Non-classic congenital adrenal hyperplasia due to 21-hydroxylase deficiency revisited: an update with a special focus on adolescent and adult women. Hum Reprod Update (2017) 23:580-99. doi: 10.1093/humupd/dmx014

76. Barnes RB, Rosenfield RL, Ehrmann DA, Cara JF, Cuttler L, Levitsky LL, et al. Ovarian hyperandrogynism as a result of congenital adrenal virilizing disorders: evidence for perinatal masculinization of neuroendocrine function in women. J Clin Endocrinol Metab. (1994) 79:1328-33.

77. Billig H, Furuta I, Hsueh AJ. Estrogens inhibit and androgens enhance ovarian granulosa cell apoptosis. Endocrinology (1993) 133:2204-12. doi: 10.1210/endo.133.5.8404672

Conflict of Interest Statement: The authors declare that the research was conducted in the absence of any commercial or financial relationships that could be construed as a potential conflict of interest.

Copyright (ㅇ 2018 Franks and Hardy. This is an open-access article distributed under the terms of the Creative Commons Attribution License (CC BY). The use, distribution or reproduction in other forums is permitted, provided the original author(s) and the copyright owner(s) are credited and that the original publication in this journal is cited, in accordance with accepted academic practice. No use, distribution or reproduction is permitted which does not comply with these terms. 